\title{
STUDY OF GREGARINE BIDARI OF BEETLES, RHYTINOTA ESCHSCHOLTZ AND GREGARINE BALTTARUM FROM COCKROUCH, PERIPLANETA AMERICAMA FROM MARATHWADA REGION MS
}

\author{
1Ashwini S Netane and 2 Rajendra R. Dandawate \\ 1. Research Student, Department of Zoology, Dr Babasaheb Ambedkar \\ Marathwada University, Aurangabad \\ Email ashwiniravi05@gmail.com \\ 2. Department of Zoology, Mula Education Society's Arts, Commerce and \\ Science Collage Sonai, Dist Ahmednagar \\ Email drajendra2006@gmail.com
}

Communicated: 28.02 .21

\begin{abstract}
:
In present work a study has been carried out on insect intestinal Gregarine species from Marathwada region. It was found that, Gregarina bidari and Gregarina blattarum are new species found in Marathwada region from Rhytinota eschscholtz and Peripleneta americana having site of infestation in mid intestine. The morphological characteristic of both the species were compared with other species from same genus from different localities. The work was done from January 2018 to December 2018.
\end{abstract}

Keywords: Gregarines, Toxoplasma, vertebrate, Apicomplexa, insect.

\section{INTRODUCTION:}

A review of the literature on gregarines reveals that mostly these parasites infect a large number of non-chordates hosts. Although a few species are reported from the protochordate viz. The ascidians (Hymen 1940). They do not see to infect they craniate's vertebrates. In the invertebrates' group they have been reported from the following phyla. Coelenterate, Platyhelminthes, Annelida, Arthropod, Mollusca\& Echinodermata (Kamm, 1922) among these the animals that most commonly harbor the gregarines are the arthropod host.

According to Watson (1916), gregarines were probably first seen by Redi in 1708 , through there artiest recorded description is that of Dufour in 1818, Kolliker (1848) published an 'elaborate Meroir on the group was perhaps the first to seen the organism in syzygy. It is this characteristic which caused Dufour in coin the term. Gregarines for them 20 years earlier, syzygy may in fact be a sexual response. It is hard to explain such a particular host distribution. The complexity of both gregarine morphology $\&$ life history makes it all but certain that they are a very ancient group having had. Amoji SD (1973) ${ }^{2}$ study on gregarine parasite from Hemiptera insect. Gregarines belongs phylum Apicomplexa. They are also called as called Sporozoan parasites. Bausanarao (1961) 3Describe a new species Cephaline gregarine from the beetle Gonocephalum brachyelytra. The name Apicomplexa means apical complex. These parasites also cause malaria. Bodyleva NN 
$(1963)^{4}$ study on gregarine, Enterocyte from the colon larvae, due to these are dangerous parasites of humans.

Utangi J C and Desai (1957) ${ }^{5}$ describe new species of gregarins from xylophagus tennites. Dharwar. Vincent M (922) ${ }^{6}$ focus on new Gregarine pyaininnanobii from intentional parasite of Anobium paniceum. The present research in gregarines is started from 2008 in protozoology lab BAMU Aurangabad for the analysis of the prevalence $\&$ systematize of the various Gregarine parasites from Arthropod hosts.

Yaman M. (2002) $)^{9}$ study on Gregarma phyllotretae 1 Hoshide, 1953 a protozoan parasite of hefiea beetles, phyllotreta undulate and Patra (coleopteran: chrysomelidae) in Turkey Apple. Latar on Prasadan PK, (2001) 10found new species of Gregarines in the Crabs from south india. Chakraborti J, Bandyopadhyay (2010) 11 works on Sporozoea) in the shrimp Peneaus monodon in Sundarbans.

\section{Life cycle of gregarines: Intestinal gregarine parasites of beetles: -}

The apical complex is present, they are often expelled with the faces, in marine polychaetas, and white spheres and can be quite large, they can be identified with eye.

Walker $\mathrm{MH},(1979)^{7}$ focus on structure of Gregarinag amhami. They are also called "pearls the gamete from the two Gamont fertilize within the cyst to form diploid zygotes, called oocyst or sporocysts, form which haploid sporozoites, are found. Watson JM (1945) ${ }^{8}$, works on a new species from cockroach.Most of the life cycle, gregarines are haploid. Only when the two gametes fuse to form zygote, from which embryo develops, later on adult get develops.

\section{MATERIALS\& METHODS:}

Different host specimens Collected from the field in $\&$ around Aurangabad city in region of Maharashtra, were brought to the laboratory \& were maintained alive in insect, beetles \& cockroaches were found threw well for a week's time in these conditions as for as possible host specimens were examined for their protozoan parasite on the day of collection in order to reduce the chances of definition due to starvation a total number of insect host 100 , Beetles host $145 \&$ Cockroaches host 95 in four month.ie. July 2014- October 2014.

\section{Preparation of Permanent Slides:}

Staining of gregarines (using tangstophoric acid hematoxylin). Mixed fecal content in saline water makes a thick smear on a clean slide \& immerse it. White still wet in schaudinn's fixative for $20 \mathrm{~min}$ pass the through the following solution.

\section{RESULT AND DISCUSSION:}

\section{Cephalont: -}

The cephalont is ovoid in shape and measures $17-30 \mu \mathrm{m}$ in length and $12 \mu \mathrm{m}$ in breadth. The epimerite is simple sessile structure and measures about $22 \mu \mathrm{mto} 27 \mu \mathrm{m}$. The protomerite is hemispherical in structure with $5 \mu \mathrm{m}$ in length and $15 \mu \mathrm{m}$ in breadth The nucleus is spherical. The parasite enters into trophic stage which is broadly spherical in shape. The protomerite is dome shaped the deutomerite is cylindrical in shape The general appearance of the associated individuals is elongated cylindrical. In the primate the deutomerite has broader while the satellite is broadest at the anterior and tapering at posterior end the nucleus is oval in shape in the primate. It is situated centrally in the satellite and is located at posterior region of the body Cyst is spherical in shape. It measures about 160 umin diameter after 4 to 6 days cysts became mature and form a long spore ducts are 
distinctly seen radiating in different directions through which spores are released in chains. The spores are barrel shaped It measures $3 \mu \mathrm{m}$ in length and $2 \mu \mathrm{min}$ breadth

\section{Comments:}

This species is similar in its body shape with medium size body the new species gregarine described by Amoji (1976) Bidar Karnataka, India. The species described by present author is Gregarina bidari, shows variations in dimensions. The present species is slightly smaller than previous one in all respects nucleus is anterior in Amoji's species which is anterior, centrally placed or posterior in present species Host of the Amoji's species is Pseudo lops whereas present author found the infection in There are variations in dimensions in the species of Amoji and present author, Rhytinota sp. So, the species described by present author

\section{Cephalont:}

The cephalont found attaches to the gut epithelium of the host, Cephalont measures about 40.10 to $55.3 \mu \mathrm{m}$ in length and 20.6 to $31.1 \mu \mathrm{m}$ at width. The protomerite is spherical in shape and 8.3 to $10.9 \mu \mathrm{m}$ in length and 11.65 to $1431 \mu \mathrm{m}$ in width. Deutomerite is oval elongated in length and measures about 30.5 to $38.15 \mu \mathrm{m}$ is length. There is clear indentation is found at the junction between epimerite and protomerite, the nucleus is spherical in shape and is situated centrally. It measures less than $10 \mu \mathrm{m}$. The sporont is elongated and broadly ovoid. It measures 50.4 to $63.2 \mu \mathrm{m}$ length and 26.4 to $33.6 \mu \mathrm{m}$ is width. The deutomerite is elongated ovoid, the maximum width is at the $1 / 3$ anterior region. The length of deutomerite is 40.8 to $46.8 \mu \mathrm{m}$. protomerite is hemispherical in shape. It measures 9.6 to $14.6 \mu \mathrm{m}$ in length and 11.65 to $17.3 \mu \mathrm{m}$ is width. Septum constriction is concave. The endoplasm is yellowish brown colour and finely granular. Nucleus is spherical, typically with single spherical. Nucleolus. It is less than $10 \mu \mathrm{m}$ in diameter and placed at anterior part of deutomerite. The two uniting gamonts were clearly visible to form a cyst which later develops into a mature cyst.

The shape of the body in the both species of (Hooger and Gulbhile) is elongated, cylindrical and in the present species it is broadly ovoid. The nucleus is ovoidal to spherical in previous species (Hoogar) which is spherical in present species and in V.D. Gulbhile species. In the present species shape of protomerite is hemispherical, it is similar to the species described by (Hooger) by diferent than that of the Gulbhile's species which is rectangular, All the dimensions shows that the present species is very small as compare to the previous species Comparative account of the present species with Hooger, V.D. Gulbhile is given in table (5).

\section{CONCLUSION:}

From above work it is concluded that the phylum Apicomplexa and species Gregarine bidari and Gregarina blattarum was reported as new species of Rhytinota species Family Gigrarinadeae, the shape of the body in the both in the gregarine bidari medium size body sea like deutomerite with the wide protomerites and small size sporocyst and exactly like the new species gregarine bidari by described by. The second is Gregarina blattarum from Cockroach is elongated, cylindrical and in the present species it is broadly ovoid. the nucleus is ovoidal into the spherical in previous species (Hoogar) which is spherical, both these types of species found in Marathwada region

\section{ACKNOWLEDGMENT:}

The authors are highly thankful to Principal Arts, Commerce and Science Collage Sonai Dist. Ahmednagar for providing laboratory facilities. 


\section{REFERENCES:}

Amoji S.D. and Kori S.S. (1991): Levinetagul bargaenmsis sp. Nov a new Actinocephalid gregarine of an odonate insect. The Indian zoologist, 15 (land 2):41-44.

Amoji S.D. and Rodgi S.S. (1973): Occurrence of an Actinocephalid gregarine in the gut of Hemiptera. pratesquadrinota his, Fabr. Cur. Set. 42(21): 755. - Baudoin. J. (1966): A propos d tine gregarine novel's Leliyan Limnophill new sp. Prostistologica. 2(4): 3944.

Bausana Rao. K.S.P. (1962): On a new cephaline gregarine (protozoa) from the But of the beetle, Gonocephalum brachyelytra Proc. All India Cong. Zool, PL. 2: 697-592

Bodyleva, N.N. (1963): A cytochemical study of different developmental stages of the gregarine, Enterocystis from the colon larvae, Man pisio, Prost, 3: 35-43.

Utangi, J.C. and Desai, RN. (1962): On some new gregarines from the non xylophagustennites. Specultermes cyclopssihalensis from Dharwar (Indin). Jour. Anium. Morph Physiol, 92): 97-109.

Vincent, M. (1922): On the life history of a new Gregarine Pyainiaanobii n. sp. Intestinal parasite of Anobium Paniceum L (Coleoptera). Parasitol. 14299-306.
Walker, M.H. Mackenzie, C. Bainbridge, S.P. and Orme, C. (1979): A Study $f$ the structure and gliding movement of Gregarin agamhami. J. Protozool, 26(4): 566-574.

Watson, J.M. (1945): A new Sporozoan, Gregarine arhyporohian sp. From a tropical cockroach, Rhiparobia Madraep, Parastrol, 36: 195-198.

Yaman. M. (2002): Gregarma phyllotretael Hoshide, 1953 a protozoan parasite of hefiea beetles, phyllotreta undulate and Patra (coleopteran: chrysomelidae) in Turkey Apple. Enjomol Zool. 37: 649-653.

Prasadan PK, Janardanan PK. (2001) Three new species of Gregarines (Apicomplexa: Sporazoen: Porosporidae) in the Estuarine Crabs from Kerala, India. Acta Protozool. 40.303-309.

Chakraborti J, Bandyopadhyay PK. (2010) J Parasitic Dies Firstrecond of a parasitie septate gregarines (Apicomplexa: Sporozoea) in the shrimp Peneaus monodon in Sundarbans of West Bengal; 34(1):40-3. Doi: 10.1007/s12639-010- 0002-7.

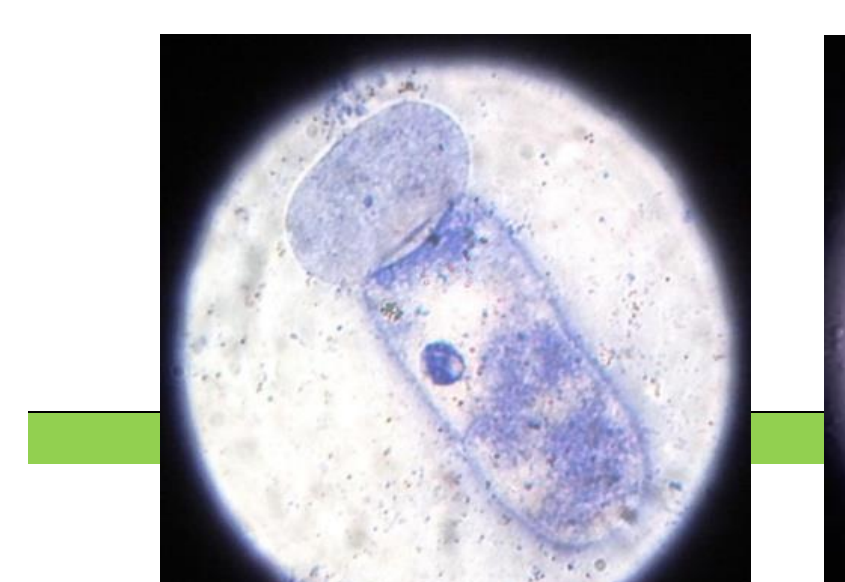




\section{Classification}

\begin{tabular}{|l|l|}
\hline Kingdom: - Annemalia (Parasite) & Kingdom -Animalia (Host- Beetles) \\
\hline Sub Kingdom: - Protozoa Phylum & - \\
\hline Phylum: - Apicomplexa & Phylum-Arthropoda \\
\hline Class: - Sporozoea & Class-Insecta \\
\hline Sub Class: - Gregarinia & - \\
\hline Order: - Eugregarinida & Order-Coleopetera \\
\hline Family: - Gregarinidae & Family-Tenebrionidae \\
\hline Genus: - Gregarina & Genus-Rhytinota \\
\hline Species: - bidari & Species-eschecholtz \\
\hline
\end{tabular}

Table. No 1 .

G. badari is morphometric comparison of the species of Genes Gregarina (preset author) with G. rigida, G. measomorphi, all measurements are in microns.

\begin{tabular}{|l|l|l|l|l|}
\hline $\begin{array}{l}\text { Comparative } \\
\text { Characters }\end{array}$ & $\begin{array}{l}\text { G. rigida (Hall) } \\
\text { Ellis }\end{array}$ & $\begin{array}{l}\text { G. msoomarphi } \\
\text { Davdhar }\end{array}$ & G. bidari sp. & $\begin{array}{l}\text { G. bidari described } \\
\text { by present author }\end{array}$ \\
\hline Body shape & $\begin{array}{l}\text { Cylindrical } \\
1425 \mu \mathrm{m}\end{array}$ & $\begin{array}{l}\text { Ellipsoidal } \\
300 \mu \mathrm{m}\end{array}$ & $\begin{array}{l}\text { Massive barrel } \\
\text { shape } 550 \mu \mathrm{m}\end{array}$ & $\begin{array}{l}\text { Massive barrel shape } \\
470 \mu \mathrm{m}\end{array}$ \\
\hline Protomerite & Flattened & Sub-globular & Dome shaped & Dome shaped \\
\hline Epimerite & Hyaline knob & Sub-globular & Knob-like & Knob-like \\
\hline Host & Acrididae & $\begin{array}{l}\text { Mesomorphus } \\
\text { Velliger Blanch }\end{array}$ & Pseudo laps Sp. & Rhytinota Sp. \\
\hline Locality & Lincoln \& Urbana & Dharwad India & Bidar India & Aurangabad India \\
\hline
\end{tabular}

\section{Gregarina Blattarum}

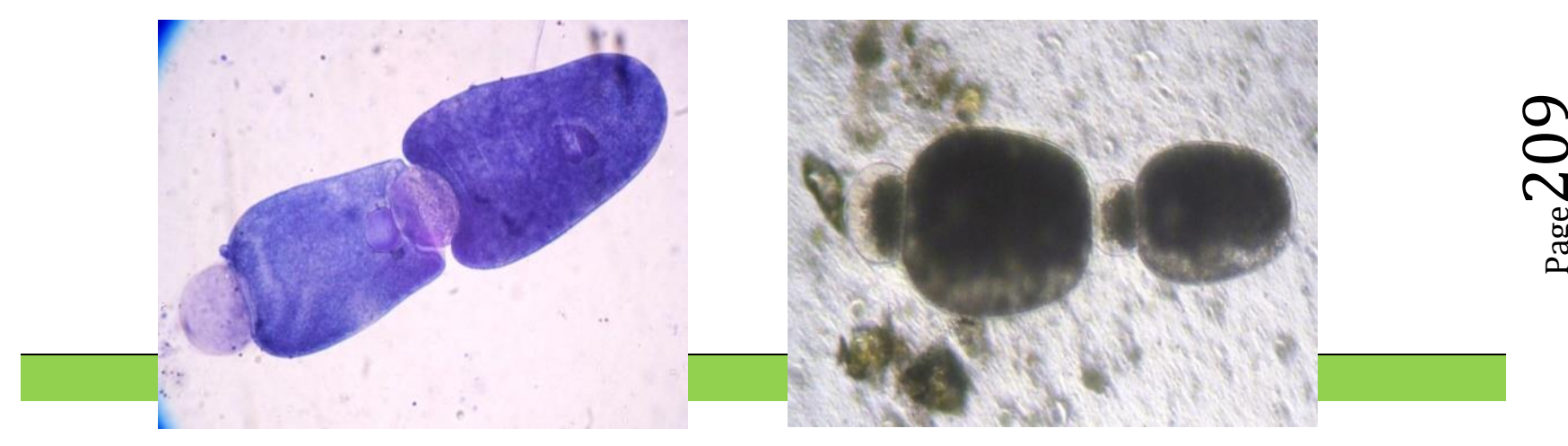


Fig. No.2: Images of Gregarina blattarum

\section{Classification}

\begin{tabular}{|l|l|}
\hline Phylum- Apicomplexa (Parasite) & Host (Cockroach) \\
\hline Class - Sporzoa & Class- Insecta \\
\hline Order: - Eugregarinida & Order-Blattodea \\
\hline Family: - Solitaroidae & Family-Corydiidae \\
\hline Genus: - Gregarina & Genus -Periplaneta \\
\hline Species: -.blattarum & Species -americana \\
\hline
\end{tabular}

\section{Table. No 2.}

G. blattarum is morphometric comparison of the species of Genus Gregarina (present author) with G. blattarum V.N. Hoonger (1988), G. blattarum V.D. Gulbhile (2005), All measurements are in microns.

\begin{tabular}{|l|l|l|l|l|}
\hline $\begin{array}{l}\text { Sr. } \\
\text { No. }\end{array}$ & Particulars & $\begin{array}{l}\text { G. blattarum V.N. } \\
\text { Hooger (1988) }\end{array}$ & $\begin{array}{l}\text { G. blattarum V.D. } \\
\text { Gulbhile (2005) }\end{array}$ & $\begin{array}{l}\text { G. blattarum } \\
\text { Present author }\end{array}$ \\
\hline 1. & $\begin{array}{l}\text { Body shape and } \\
\text { dimension }\end{array}$ & $\begin{array}{l}\text { Elongated, cylindrical } \\
\text { bottle like }\end{array}$ & $\begin{array}{l}\text { Elongated cylindrical } \\
\text { bottle likeL-460-510 } \mathrm{mm}\end{array}$ & $\begin{array}{l}\text { Elongated broadly } \\
\text { avoid L-50.4- } \\
67.2 \mu \mathrm{mW}-26.4- \\
33.6 \mu \mathrm{m}\end{array}$ \\
\hline 2. & Protomerite & Oval, hemispherical & Large, Rectangular & Hemispherical \\
\hline 3 & Sporocysts & $\begin{array}{l}\text { Cylindrical with flat.9 } \\
\mathrm{x} 4 \mu \mathrm{m}\end{array}$ & $\begin{array}{l}\text { Cylindrical with flat. } \\
7 \times 3 \mu \mathrm{m}\end{array}$ & $\begin{array}{l}\text { Cylindrical with } \\
\text { flat. } \\
8 \times 3 \mu \mathrm{m}\end{array}$ \\
\hline 4 & Host & Periplaneta americana & Periplaneta americana & $\begin{array}{l}\text { Periplaneta } \\
\text { americana }\end{array}$ \\
\hline 5 & Locality & $\begin{array}{l}\text { Gulbarga Karnataka } \\
\text { India }\end{array}$ & $\begin{array}{l}\text { Parali (v) Beed District } \\
\text { (MS) India }\end{array}$ & $\begin{array}{l}\text { Marathwada region } \\
\text { (MS) India }\end{array}$ \\
\hline
\end{tabular}

